\title{
Development, validation and application of an ultra-sensitive two-site enzyme immunoassay for human follistatin
}

\author{
L W Evans, S Muttukrishna ${ }^{1}$ and N P Groome
}

School of Biological and Molecular Sciences, Oxford Brookes University, Headington, Oxford OX3 OBP, UK and ${ }^{1}$ Nuffield Department of Obstetrics and Gynaecology, University of Oxford, John Radcliffe Hospital, Headington, Oxford OX3 9DU, UK

(Requests for offprints should be addressed to L W Evans, School of Biological and Molecular Sciences, Oxford Brookes University, Gipsy Lane, Headington, Oxford OX3 OBP, UK)

\begin{abstract}
Recent studies have found follistatin to be an important regulator of activin bioactivity. Whilst a number of assay formats have been described, all are of limited sensitivity and require the use of isotopes. Many use polyclonal antibodies. Furthermore, a wide range of follistatin preparations have been used as standards, complicating inter-laboratory comparison.

We now describe an ultra-sensitive two-site enzyme immunoassay using a pair of mouse monoclonal antibodies raised against follistatin 288. The presence of sodium deoxycholate and Tween 20 in the diluent gave results for total (free and activin-dissociated) follistatin. The assay had a detection limit of $<19 \mathrm{pg} / \mathrm{ml}$ and recovery of spiked follistatin 288 from amniotic fluid, serum, seminal plasma, human follicular fluid and granulosa cell conditioned medium averaged $100 \cdot 7 \pm 7 \cdot 5 \%, 89 \cdot 1 \pm 5 \cdot 5 \%, 98 \pm 4 \cdot 9 \%$, $96 \pm 7 \cdot 2 \%$ and $123 \cdot 9 \pm 11 \%$ respectively. The intra- and interplate coefficients of variation were $<5 \%$. An excess of activin-A $(50 \mathrm{ng} / \mathrm{ml})$ prior to assay did not affect follistatin recovery. Inhibin- $\mathrm{A}$, inhibin- $\mathrm{B}$, activin- $\mathrm{A}$, activin-B and activin-AB had minimal cross-reactivity $(<0 \cdot 3 \%)$. However, follistatin 315 had a significant cross-reaction (9.9\%).

Serially diluted human samples gave dose-response curves parallel to the standard. Pooled human follicular fluid
\end{abstract}

contained high concentrations of follistatin $(\sim 242 \mathrm{ng} / \mathrm{ml})$. Follistatin was also found in maternal serum during pregnancy (first trimester $\sim 0.8 \mathrm{ng} / \mathrm{ml}$, third trimester $\sim 2.8 \mathrm{ng} / \mathrm{ml})$, normal male serum $(\sim 0.45 \mathrm{ng} / \mathrm{ml})$, amniotic fluid (sixteen week $\sim 3.63 \mathrm{ng} / \mathrm{ml}$, term $\sim 0.89 \mathrm{ng} / \mathrm{ml}$ ), seminal plasma $(2 \cdot 4-30 \mathrm{ng} / \mathrm{ml})$ and human granulosa cell conditioned media $(\sim 0.44 \mathrm{ng} / \mathrm{ml})$. Serial serum samples taken throughout the menstrual cycle of ten women showed fluctuating follistatin concentrations $(\sim 0.62 \mathrm{ng} / \mathrm{ml})$ with no apparent relationship to the stage of the cycle. Interestingly, pooled serum from postmenopausal women appeared to have higher follistatin levels than any of the normal women $(\sim 1.4 \mathrm{ng} / \mathrm{ml})$.

The possible presence in certain samples of mixtures of follistatin isoforms with different immunoreactivities poses major problems of interpretation in this and all other current follistatin immunoassays. Further work is needed to identify the major immunoreactive forms in different tissues and fluids. Nevertheless, the new assay has a number of advantages over previous assays and should prove a useful tool for various clinical and physiological studies.

Journal of Endocrinology (1998) 156, 275-282

\section{Introduction}

Follistatin is a monomeric glycosylated polypeptide chain which was initially identified in and isolated from both bovine and porcine follicular fluids on the basis of its inhibition of pituitary follicle-stimulating hormone (FSH) secretion (Robertson et al. 1987, Ueno et al. 1987, Ying et al. 1987). It is well documented that follistatin exerts its inhibitory effect on FSH secretion by neutralizing activin bioactivity (Nakamura et al. 1990, Kogawa et al. 1991, Shimonaka et al. 1991, de Winter et al. 1996). There are two main forms of mature mammalian follistatin (FS) which occur as a result of alternative modes of precursor mRNA splicing, giving core proteins of 315 amino acids and the carboxy-truncated variant of 288 amino acids (FS315 and FS288) (Shimasaki et al. 1988, Michel et al. 1990, Inouye et al. 1991). Further variations in the molecular weight of mature follistatin occur as a result of varying degrees of glycosylation (Inouye et al. 1991, Sugino et al. 1993).

Previous immunoassays for follistatin have either been radioimmunoassay (RIA) or immunoradiometric assay (IRMA) formats (Table 1). The most sensitive of these assays has a detection limit of $500 \mathrm{pg} / \mathrm{ml}$ follistatin. This is two orders of magnitude less sensitive than the inhibin enzyme-linked immunosorbent assays (ELISAs) from our laboratory (Groome et al. 1994, 1995, 1996). These previous follistatin assays have other disadvantages, including 
Table 1 Characteristics of previous immunoassays

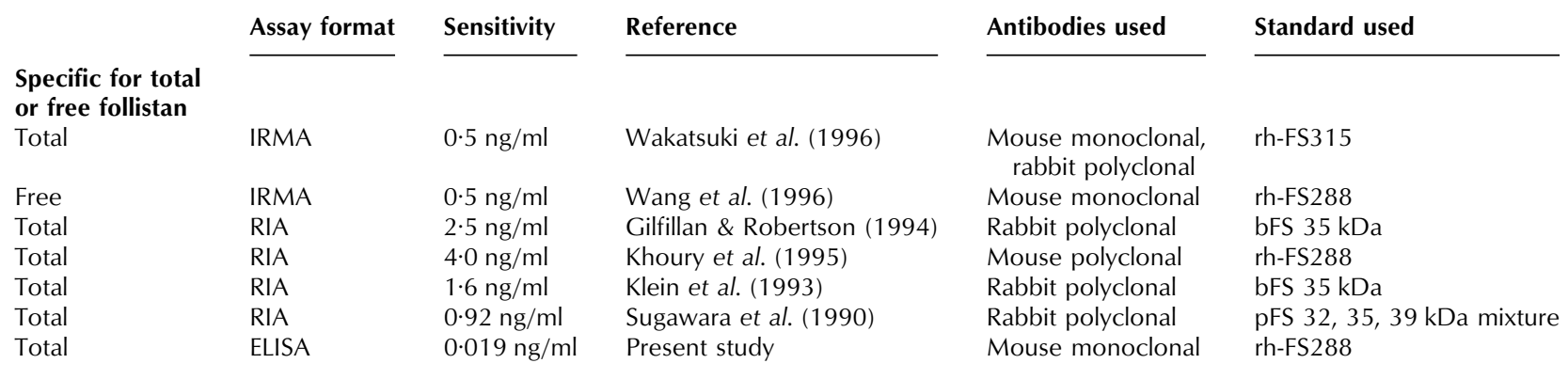

the use of hazardous short-lived isotopic reagents. All except Wang et al. (1996) use polyclonal antisera. By contrast, previous immunoassays developed in this laboratory for inhibin-A, inhibin-B, inhibin Pro- $\alpha \mathrm{C}$, activin-A and activin- $\mathrm{AB}$ all use exclusively monoclonal antibodies, a non-isotopic detection system and are highly sensitive (Groome et al. 1994, 1995, 1996, Knight et al. 1996, Evans et al. 1997).

The aim of the present work was to develop a similar ELISA for total follistatin. Use is made of a dissociating solution (Poncelet \& Francimont 1994, McFarlane et al. 1996) to disrupt activin/follistatin complexes. The validated assay appears to be a suitable tool for physiological and clinical studies. In order that our collaborators using the assay have a reference on the assay validation to cite in their work, we present here these studies.

\section{Materials and Methods}

\section{Antibody production}

Female Balb/c mice were immunized subcutaneously with $20 \mu \mathrm{g}$ recombinant human (rh)-FS288 (a gift from the National Hormone and Pituitary Program and the National Institute of Diabetes and Digestive, and Kidney Diseases, Bethesda, MD, USA) in an emulsion with Freund's complete adjuvant. The immunization was repeated on two further occasions at monthly intervals in Freund's incomplete adjuvant, before finally boosting intravenously with rh-FS288 (total $100 \mu \mathrm{g}$ in saline). The spleen was removed and the splenocytes were fused to Sp2/0 myeloma cells using polyethylene glycol following a standard fusion protocol (Galfre \& Milstein 1981). Hybridoma supernatants were screened on a 96-well plate coated with $\mathrm{rh}-\mathrm{FS} 288(0 \cdot 2 \mu \mathrm{g} / \mathrm{ml}$ in $0.2 \mathrm{M}$ sodium bicarbonate buffer, $\mathrm{pH} 9 \cdot 4$ ) following a screening protocol described elsewhere (Groome et al. 1995). Positive clones were expanded and recloned in methyl cellulose (McCullough \& Spier 1990). The supernatants from these single clones were titrated against rh-FS288 $(0 \cdot 2 \mu \mathrm{g} / \mathrm{ml})$ under a standard ELISA protocol (Groome et al. 1995). On the basis of these experiments two clones (29/9 and 17/2) were selected and isotyped with a commercial kit (Sigma Chemical Co., Poole, Dorset, UK). Both clones were found to secrete immunoglobulin G1 (IgG1) antibodies, and were grown to produce ascitic fluid in pristaneprimed BALB/c mice (Harlow \& Lane 1988). Purification of $\mathrm{IgG}$ was carried out using protein-G affinity chromatography (Prosep-G; Bioprocessing, Consett, Co. Durham, UK).

\section{9/9-Coated 96-well plates}

29/9 Monoclonal antibody, diluted in $0.2 \mathrm{M}$ sodium bicarbonate buffer, $\mathrm{pH} 9 \cdot 4$, was coated by simple adsorption onto 96-well ELISA plates (Life Technologies Ltd, Paisley, Renfrewshire, UK) overnight at room temperature $(10 \mu \mathrm{g} / \mathrm{ml})$. The following day the plates were banged to dryness on paper towelling, then $100 \mu \mathrm{l}$ dry coat reagent/ well (Bionostics, Wyboston, Bedfordshire, UK) were added to the plates. After $1 \mathrm{~h}$ incubation at room temperature the plates were banged to dryness and stored in a sealed box.

\section{Sample/standard preparation}

All samples used in this study were obtained from patients who had given informed consent for collection approved by the appropriate ethical committee. Menstrual cycle serum samples were taken from normal women who had given informed consent for blood collection approved by the Oxfordshire Health Authority. The standard material used in the assay was rh-FS288. Both standards and samples were diluted in dissociating solution $(84 \mathrm{mmol}$ sodium deoxycholate, 3.4\% (v/v) Tween 20, 1\% (w/v) BSA, 5\% (v/v) mouse serum in PBS). Standards were prepared by serially diluting the stock rh-FS288 to give a high standard of $2500 \mathrm{pg} / \mathrm{ml}$ and a low standard of $19.53 \mathrm{pg} / \mathrm{ml}$.

\section{ELISA for total follistatin}

Duplicate $50 \mu \mathrm{l}$ amounts of standard/sample were added to wells on the plate, which was then sealed and incubated 


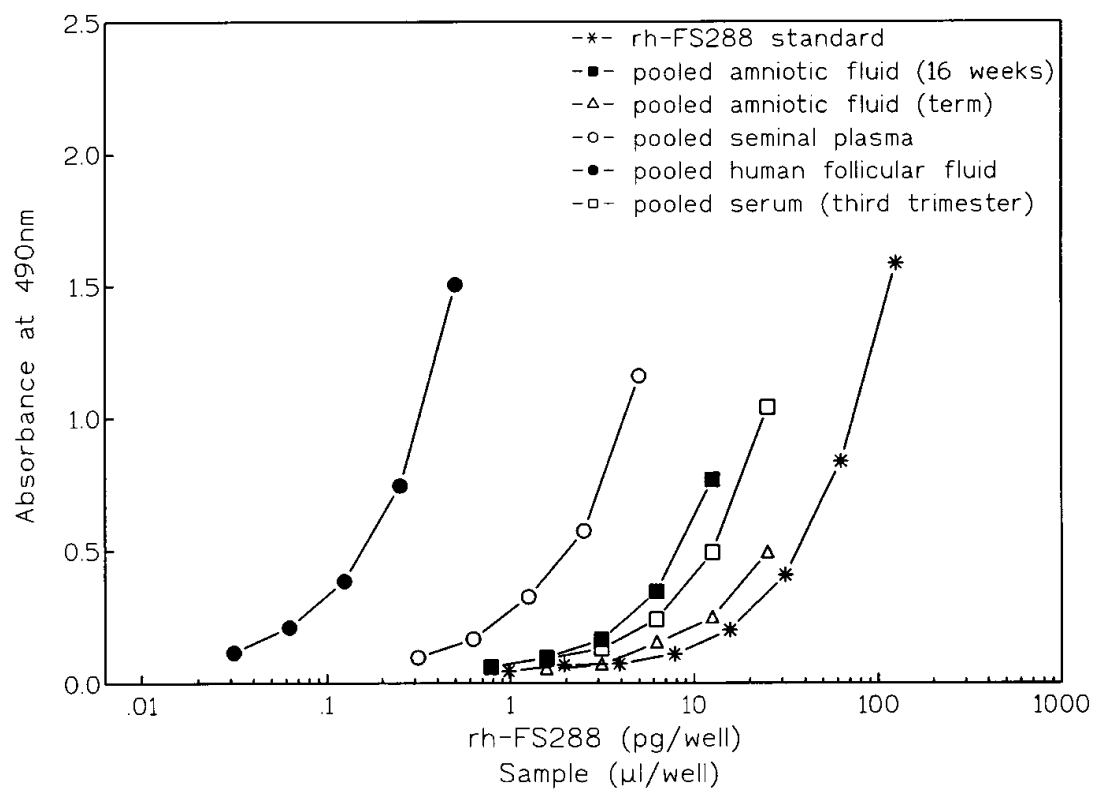

Figure 1 Dose-response curves for various human biological fluid samples containing follistatin using the optimized ELISA procedure.

overnight stationary at room temperature in a sealed moist box. The following day, the plate was washed and to each well was added $50 \mu \mathrm{l}$ of approximately $1 \mu \mathrm{g} / \mathrm{ml}$ solution of the Fab fragment of clone 17/2, which had previously been coupled to alkaline phosphatase by heterobifunctional chemistry as described previously (Ishikawa et al. 1983). This was diluted in Tris conjugate buffer: $1 \%(\mathrm{w} / \mathrm{v})$ BSA in $25 \mathrm{mM}$ Tris $-\mathrm{HCl} \mathrm{pH} 7.5$ containing $0.15 \mathrm{M}$ $\mathrm{NaCl}$ and $0.5 \%(\mathrm{v} / \mathrm{v})$ Tween 20 . The optimal concentration of this material differed from batch to batch and was determined empirically. After $2 \mathrm{~h}$ incubation in a moist box at room temperature, the plate was washed thoroughly, and banged to dryness on paper towelling. Alkaline phosphatase substrate $(50 \mu \mathrm{l})$ was added to each well (ELISA Amplification System; Life Technologies Ltd) and the plate incubated for $2 \mathrm{~h}$ stationary at room temperature. Amplifier solution $(50 \mu \mathrm{l}$; from the above kit) was then added to each well and the ensuing chromogenic reaction was stopped by adding $0 \cdot 4 \mathrm{M} \mathrm{HCl}(50 \mu \mathrm{l} /$ well $)$ once colour began to develop in the zero analyte wells and the top standard had an absorbance of approximately $1 \cdot 8$. The well absorbances were read at $490 \mathrm{~nm}$ with a reference wavelength set at $620 \mathrm{~nm}$ using a microplate reader (EL340; Bio-Tek Instruments, Winsooki, VT, USA). Data were interpreted using Kineticalc EIA software (Bio-Tek Instruments).

\section{Statistical analysis}

To determine whether dose-response relationships of serially diluted standard and test samples were identical

(parallel), the slope values ( $\pm 95 \%$ confidence intervals) of $\log -\log$ transformed data for each response curve were compared by linear regression. The curves were deemed to be parallel if the slopes ( $\pm 95 \%$ confidence intervals) were found to overlap.

\section{Results}

Validation studies

Specificity The cross-reactivities of inhibin-A, inhibin$\mathrm{B}$, activin-A, activin-B, -activin-AB and FS315 were all

Table 2 Concentrations of follistatin ( $\mathrm{ng} / \mathrm{ml}$ except where stated otherwise) in various human biological fluid samples. Values are means \pm S.D.

\section{Subject group $(n)$}

First trimester serum (4)

Third trimester serum (7)

Normal menstrual cycle serum (10)

Normal male serum (3)

Week 16 amniotic fluid (5)

Term amniotic fluid (7)

Seminal plasma (4)

Human granulosa cell cultured media (13)

Pooled postmenopausal serum

Pooled human follicular fluid

Placental homogenates (ng/g) (3)
Follistatin $(\mathrm{ng} / \mathrm{ml})$

\begin{tabular}{l} 
Follistatin $(\mathrm{ng} / \mathrm{ml})$ \\
\hline \\
$0 \cdot 847 \pm 0 \cdot 26$ \\
$2 \cdot 80 \pm 0 \cdot 93$ \\
$0 \cdot 627 \pm 0 \cdot 196$ \\
$0 \cdot 450 \pm 0 \cdot 16$ \\
$3 \cdot 63 \pm 1 \cdot 50$ \\
$0 \cdot 890 \pm 0 \cdot 32$ \\
$12 \cdot 89 \pm 9 \cdot 9$ \\
$0 \cdot 44 \pm 0 \cdot 33$ \\
$1 \cdot 42$ \\
252 \\
$3 \cdot 11 \pm 0 \cdot 4$
\end{tabular}



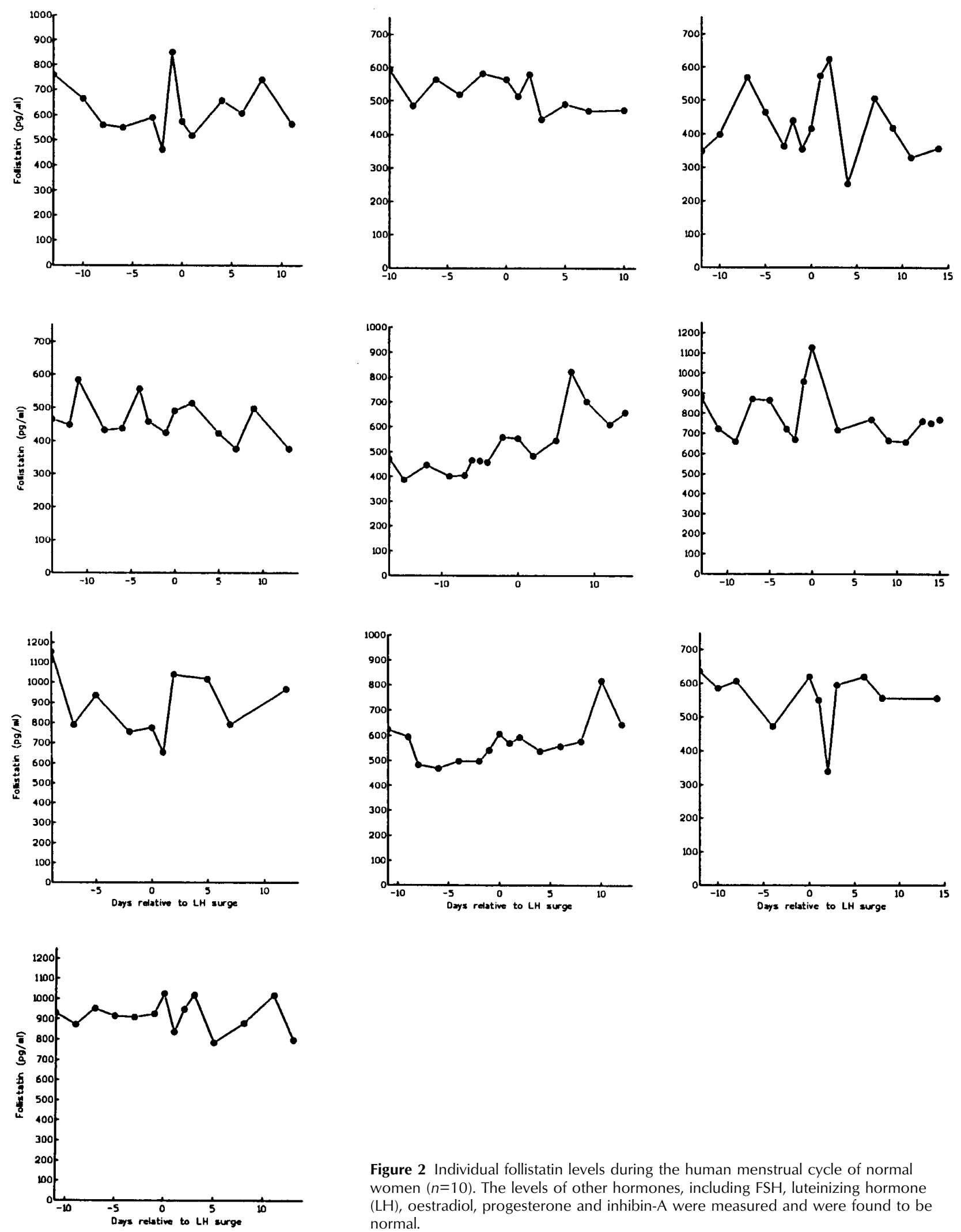

Figure 2 Individual follistatin levels during the human menstrual cycle of normal women $(n=10)$. The levels of other hormones, including FSH, luteinizing hormone $(\mathrm{LH})$, oestradiol, progesterone and inhibin-A were measured and were found to be normal. 
tested in the optimized assay. None of the above showed any cross-reaction $(<0 \cdot 3 \%)$ with the exception of FS315 $(9 \cdot 9 \%)$. Further specificity experiments were conducted to determine whether activin or inhibin interfere with the response signal to follistatin. Preincubation of FS288 standard $(0.63 \mathrm{ng} / \mathrm{ml})$ with a large excess of activin-A $(50 \mathrm{ng} / \mathrm{ml})$ for $3 \mathrm{~h}$ before assay was found to have no effect on follistatin immunoreactivity, indicating that the assay can measure total follistatin. This was also the case when follistatin was preincubated with inhibin-A $(50 \mathrm{ng} / \mathrm{ml})$.

Assay range and sensitivity The range of rh-FS288 standards used in the assay was $19-2500 \mathrm{pg} / \mathrm{ml}$. The detection limit of the assay, defined as the dose of follistatin which generated an absorbance value $=x_{\text {true blanks absorbance }}+$ $5 \times$ s.D. zero-dose sample (Porstmann \& Kiessig 1992), was $<19 \mathrm{pg} / \mathrm{ml}$.

Accuracy This was determined by 'spiking' various human test samples with a known amount of follistatin 288 standard $(0.5 \mathrm{ng} / \mathrm{ml})$ prior to assay and assessing the percentage recovery. Mean recovery values of exogenous follistatin from follicular fluid, seminal plasma, amniotic fluid, serum and granulosa cell conditioned medium were $96 \pm 7 \cdot 2,98 \pm 4 \cdot 9,100 \cdot 7 \pm 7 \cdot 5,89 \cdot 1 \pm 5 \cdot 5$ and $123 \cdot 9 \pm$ 11\% respectively. Parallelism (Fig. 1) between the standard and the various biological fluids tested was confirmed by regression analysis of log-log transformed data. The slopes of the lines ( $\pm 95 \%$ confidence intervals) were shown to overlap. Thus it can be stated that the slopes of the lines were not significantly different.

Precision Replicates $(n=8)$ of various concentrations of rh-FS288 standard were assayed on separate plates $(n=4)$ to determine assay coefficients of variation. The mean intra- and interplate coefficients of variation were both $<5 \%$. The coating antibody used for each plate was from the same batch, as was the detection antibody. Due to both these antibodies being produced by monoclonal cells lines there is no reason for the precision of the assay to vary from batch to batch.

Follistatin concentrations in human samples Table 2 shows the concentrations of follistatin measured in various human biological fluids. Human follicular fluid contained the highest concentration of follistatin $(\sim 250 \mathrm{ng} / \mathrm{ml})$. In pregnancy, serum follistatin levels were found to increase from $847 \pm 260 \mathrm{pg} / \mathrm{ml}(n=4)$ in the first trimester, to $2800 \pm 930 \mathrm{pg} / \mathrm{ml}(n=7)$ in the third trimester. By contrast, concentrations in human amniotic fluid were found to decrease as gestation progressed from $3630 \pm 1500 \mathrm{pg} /$ $\mathrm{ml}(n=5)$ at week 16 , to $890 \pm 320 \mathrm{pg} / \mathrm{ml}(n=7)$ at term. Placental homogenates collected at term $(n=3)$ had $3 \cdot 11 \pm 0 \cdot 4 \mathrm{ng} / \mathrm{g}$ follistatin.

Fig. 2 shows the individual follistatin levels during the menstrual cycle of normal women $(n=10)$. There was no consistent trend in the serum follistatin levels. Concentrations ranged from $\sim 250 \mathrm{pg} / \mathrm{ml}$ up to $\sim 1120 \mathrm{pg} / \mathrm{ml}$ with no relationship to the phases of the cycle. Follistatin in the pooled serum of postmenopausal women (1424 pg/ $\mathrm{ml}$ ) was present at higher concentrations than that of normal menstruating women.

\section{Discussion}

The development of immunoassays for follistatin has been complicated by certain characteristics of the molecule. In some ways these are similar to difficulties previously experienced in FSH assay development (Storring 1992). The presence of multiple molecular forms in biological fluids in a variety of species (Robertson et al. 1987, Sugino et al. 1993, Yokoyama et al. 1995), together with varying degrees of glycosylation, combined with the possibility of proteolysis during sample handling all complicate follistatin assay development. Since there is no widely accepted method and no commercially available follistatin assay, the literature now contains a description of seven distinct immunoassays from groups using different labels and polyclonal or monoclonal antibodies (Table 1). Six of these are claimed to measure total follistatin, whereas Wang et al. (1996) claim that their assay is specific for free follistatin. Due to the absence of an international follistatin standard, some groups used recombinant FS288 or FS315 as standards. Others used purified individual porcine (p) or bovine (b) isoforms, or even mixtures of these. Naturally, the absolute levels of follistatin reported by the various groups vary widely.

In consequence of the above, it is impossible to reconcile all the data emerging from groups using the various assays. No assay appears to have been widely adopted, indeed the majority of assays are only used in the laboratories where they were developed. Several examples can be given of the contradictory information appearing in the literature. Gilfillan and Robertson (1994) report significantly lower total serum follistatin concentrations in human luteal phase compared with follicular phase. By contrast, Khoury et al. (1995) report no statistical variation across the menstrual cycle. The present study supports the latter finding. Serum follistatin does not appear to be primarily an ovarian product.

Several groups agree that, in the serum of pregnant women, total follistatin concentrations rise steadily with increasing length of gestation (Khoury et al. 1995, Wakatsuki et al. 1996). Our data support these findings (maternal serum follistatin concentrations: first trimester $0 \cdot 847 \pm 0.26 \mathrm{ng} / \mathrm{ml}$, third trimester $2 \cdot 80 \pm 0.93 \mathrm{ng} / \mathrm{ml})$. In marked contrast Gilfillan and Robertson (1994) found no variation throughout human pregnancy, indeed in their study all of the serum samples had follistatin concentrations within a narrow range $(3 \cdot 9-5 \cdot 2 \mathrm{ng} / \mathrm{ml})$. This included normal male serum, hypogonadal male serum, normal 
female serum, serum samples from pregnant women and serum samples from postmenopausal women. Wakatsuki et al. (1996) reported higher levels of follistatin in postmenopausal women. Whilst Gilfillan and Robertson (1994) also reported an increase with age, the magnitude was much smaller than in the Wakatsuki study. Khoury et al. (1995) found no difference with increasing age. Our data suggest that postmenopausal serum levels are elevated to the upper end of the range found in normal women.

The assay described by Wang et al. (1996) uses two monoclonal antibodies and the assay is claimed to be specific for free follistatin. This claim is based on the data shown in Fig. 2 of their paper in which activin appears to be able to inhibit the signal obtained from follistatin. However, close examination of the figure, and in particular its legend, show that approximately $20 \%$ of the signal remains even in the presence of a vast excess of activin-A (approx. 150-fold molar excess). Since only a small molar excess of activin is needed to convert all the follistatin into activin complexes we do not believe the data are correctly interpreted i.e. the assay does not specifically measure free follistatin. We would expect almost complete inhibition of signal with a small molar excess of activin-A if the assay were truly measuring free follistatin. It seems to us that a more likely interpretation of the data is that incubation of samples with the immobilized monoclonal antibody allows dissociation of the complexes permitting measurement of initially activin-bound follistatin. Thus, in modest activin excess recovery of follistatin remains quantitative. However, as activin excess increases the available solid phase antibody becomes insufficient to displace all the activin from follistatin. If this interpretation is correct, the concept of being able to assay free follistatin specifically is invalid. Further work would be needed to accept the validity of a free follistatin assay.

A major problem in all follistatin assays is the choice of standard and the ability of assays to measure each of the different follistatin isoforms. For the three main forms so far described, i.e. FS288, FS303, FS315, it would be desirable to have three totally specific assays. No assay so far described achieves this goal. Gilfillan and Robertson (1994) reported that in their assay the potencies of other forms relative to the bFS $35 \mathrm{kDa}$ standard were as follows: $31 \mathrm{kDa}, 4 \cdot 1,39 \mathrm{kDa}, 2 \cdot 6$ and $45 \mathrm{kDa}, 5 \cdot 9$. Wakatsuki et al. (1996) developed an assay for FS315 but provided no evidence for lack of reactivity with the other forms. Wang et al. (1996) developed an assay for FS288 but provided no evidence that FS315 did not cross-react. In our experience most antibodies raised to FS288 would react well with FS315 and vice versa.

Very little information is currently available about the relative concentrations of FS288, FS303 and FS315 in different biological fluids and tissues. If some tissues or fluids contain only one of the isoforms then it is of little consequence if the assay used to detect it has a potential to cross-react with other forms. However, problems of interpretation may occur if such an assay is used on other samples which contain a mixture of forms, possibly with different biological functions. In this case, precise quantification is impossible. In addition to the three major isoforms there exist a range of glycosylation variants. Nobody has tested the reactivity of each of these in immunoassays, further adding to the complexity of the situation.

As a result of these considerations all follistatin immunoassays currently available, including that in the present study, pose problems in the interpretation of results. One advantage of the present assay is that it is based on monoclonal antibodies which should give long term reproducibility of results in different laboratories. In contrast to previous studies, we have measured the cross-reaction of the FS315 variant compared with FS288 (9.9\%). Recent work suggests that follistatin in human serum may be predominantly FS315, whereas FS288 is the dominant form in follicular fluid (Schneyer et al. 1996). If this is the case, then our estimates of follicular fluid concentrations based on FS288 standards are probably reasonably accurate $(\sim 250 \mathrm{ng} / \mathrm{ml})$. However, we would expect our assay to record serum concentrations approximately $10 \%$ of their true values. This seems to be the case since Khoury et al. (1995) report serum concentrations of $8.09 \mathrm{ng} / \mathrm{ml}$ in the normal human menstrual cycle, compared with $0.5-$ $1.0 \mathrm{ng} / \mathrm{ml}$ in the present study. Wakatsuki et al. (1996) report human female serum levels as $12.5 \mathrm{ng} / \mathrm{ml}$. It is not known which forms of follistatin are present in most tissues and fluids and thus it is possible that mixtures may be found. Although our assay sensitivity for serum forms is reduced, this is compensated for by the very high starting sensitivity. Thus, normal serum levels are still readily measurable. In further studies we hope to determine the extent of cross-reactivity of FS303. We also plan to identify the major forms of follistatin in various human tissues and fluids. Only with this information can meaningful physiological studies be carried out by current immunoassays.

Our goal was to try to develop an optimized total human follistatin assay suitable for a wide range of clinical and physiological studies. The assay described here is similar in format to the inhibin assays from our laboratory. A special dissociating solution (Poncelet \& Francimont 1994, McFarlane et al. 1996) allows the assay to measure total follistatin by disrupting activin/follistatin complexes. A pair of high affinity monoclonal antibodies used in sandwich amplified ELISA format make the assay ultrasensitive $(19 \mathrm{pg} / \mathrm{ml})$, much more sensitive than the best of the previous assays (see Table 1). Use of alkaline phosphatase-labelled detection antibody and dry antibodycoated microplates give the reagents a long shelf life. The assay has been validated for human follicular fluid, human serum, amniotic fluid, seminal plasma and granulosa cell conditioned medium. It seems likely to find a wide range of applications. In due course, similar immunoassays specific for FS315 and FS303 will be needed. In view of 
the high degree of homology between human, bovine and porcine follistatins, we were surprised to find that our assay has limited ability to recognize animal follistatins. This is probably because antibodies are produced preferentially to the less conserved regions.

\section{Acknowledgements}

Thanks are due to the National Hormone and Pituitary Program and the National Institute of Diabetes and Digestive, and Kidney Diseases for the generous gift of recombinant human FS288, Dr H Sugino for the gift of recombinant human FS315, and Len Bagnall for assistance with animal work. NPG thanks the MRC for financial support, S M acknowledges the support of the Wellcome Trust and L WE was funded by Oxford Brookes University.

\section{References}

Evans LW, Muttukrishna S, Knight PG \& Groome NP 1997 Development, validation and application of a two-site enzymelinked immunosorbent assay for activin-AB. Journal of Endocrinology 52 221-230.

Galfre G \& Milstein C 1981 Preparation of monoclonal antibodies: strategies and procedures. In Methods in Enzymology, 73, pp 3-36. Eds JJ Langone \& HV Vunakis. New York: Academic Press.

Gilfillan CP \& Robertson DM 1994 Development and validation of a radioimmunoassay for follistatin in human serum. Clinical Endocrinology 41 453-461.

Groome NP, Illingworth PJ, O'Brien M, Cooke I, Ganesan TS, Baird DT \& McNeilly AS 1994 Detection of dimeric inhibin throughout the human menstrual cycle by two-site enzyme immunoassay. Clinical Endocrinology 40 717-723.

Groome NP, Illingworth PJ, O'Brien M, Priddle J, Weaver K \& McNeilly AS 1995 Quantification of inhibin pro- $\alpha \mathrm{C}$-containing forms in human serum by a new ultrasensitive two-site enzymelinked immunosorbent assay. Journal of Clinical Endocrinology and Metabolism 80 2926-2932.

Groome NP, Illingworth PJ, O'Brien M, Pai R, Rodger FE, Mather JP \& McNeilly AS 1996 Measurement of dimeric inhibin-B throughout the human menstrual cycle. Journal of Clinical Endocrinology and Metabolism 81 1321-1325.

Harlow E \& Lane D 1988 Antibodies: A Laboratory Manual. Cold Spring Harbour: Cold Spring Harbor Laboratory.

Inouye S, Guo Y, de Paolo L, Shimonaka M, Ling N \& Shimasaki S 1991 Recombinant expression of human follistatin with 315 and 288 amino acids: chemical and biological comparison with native porcine follistatin. Endocrinology 129 815-822.

Ishikawa E, Imagawa M, Hashida S, Yoshitake S, Hamaguchi Y \& Ueno T 1983 Enzyme labelling of antibodies and their fragments for enzyme immunoassay and immunocytochemistry. Journal of Immunoassay 4 209-327.

Khoury RH, Wang QF, Crowley WF, Hall JE, Schneyer AL, Toth T, Midgley AR \& Sluss PM 1995 Serum follistatin levels in women: evidence against an endocrine function of ovarian follistatin. Journal of Clinical Endocrinology and Metabolism $\mathbf{8 0}$ 1361-1368.

Klein R, Findlay JK, Clarke IJ, de Kretser DM \& Robertson DM 1993 Radioimmunoassay of FSH-suppressing protein in the ewe: concentrations during the oestrous cycle and following ovariectomy. Journal of Endocrinology 137 433-443.
Knight PG, Muttukrishna S \& Groome NP 1996 Development and application of a two-site enzyme immunoassay for the determination of 'total' activin-A concentrations in serum and follicular fluid. Journal of Endocrinology 148 267-279.

Kogawa K, Nakamura T, Sugino K, Takio K, Titani K \& Sugino H 1991 Activin-binding protein is present in pituitary. Endocrinology 128 1434-1440.

McCullough KC \& Spier RE 1990 Selection of monoclonal antibodysecreting hybridoma cell lines. In Monoclonal Antibodies in Biotechnology: Theoretical and Practical Aspects, pp 247-254. Eds J Baddiley, NH Carey, IJ Higgins \& WG Potter. Cambridge: Cambridge University Press.

McFarlane JR, Foulds LM, Pisciotta A, Robertson DM \& de Kretser DM 1996 Measurement of activin in biological fluids by radioimmunoassay, utilizing dissociating agents to remove the interference of follistatin. European Journal of Endocrinology 134 481-489.

Michel U, Albiston A \& Findlay JK 1990 Rat follistatin: gonadal and extragonadal expression and evidence for alternative splicing. Biochemical and Biophysical Research Communications 173 401-407.

Nakamura T, Takio K, Eto Y, Shibai H, Titani K \& Sugino H 1990 Activin-binding protein from rat ovary is follistatin. Science $\mathbf{2 4 7}$ 836-838.

Poncelet E \& Francimont P 1994 Two-site enzyme-immunoassays of inhibin. In Inhibin and Inhibin-Related Proteins, pp 45-54. Eds HG Burger, DM de Kretser, J Findlay, DM Robertson \& F Petraglia. Rome: Ares-Serono Symposia.

Porstmann T \& Kiessig ST 1992 Enzyme immunoassay techniques: an overview. Journal of Immunological Methods 150 5-21.

Robertson DM, Klein R, de Vos FL, McLachlan RI, Wettenhall REH, Hearn MTW, Burger HG \& de Kretser DM 1987 The isolation of polypeptides with FSH suppressing activity from bovine follicular fluid which are structurally different to inhibin. Biochemical and Biophysical Research Communications 149 744-749.

Schneyer AL, Hall HA, Lambert-Messerlian G, Wang QF, Sluss P \& Crowley WF 1996 Follistatin activin complexes in human serum and follicular fluid differ immunologically and biochemically. Endocrinology 137 240-247.

Shimasaki S, Koga M, Esch F, Cooksey K, Mercado M, Koba A, Ueno N, Ying SY, Ling N \& Guillemin R 1988 Primary structure of the human follistatin precursor and its genomic organization. Proceedings of the National Academy of Sciences of the USA $\mathbf{8 5}$ 4218-4222.

Shimonaka M, Inouye S, Shimasaki S \& Ling N 1991 Follistatin binds to both activin and inhibin through the common beta-subunit. Endocrinology 128 3313-3315.

Storring PL 1992 Assaying glycoprotein hormones - the influence of glycosylation on immunoreactivity. Trends in Biotechnology $\mathbf{1 0}$ 427-432.

Sugawara M, DePaolo L, Nakatani A, Dimarzo SJ \& Ling N 1990 Radioimmunoassay of follistatin: application for in vitro fertilization procedures. Journal of Clinical Endocrinology and Metabolism 71 $1672-1674$.

Sugino K, Kurosawa N, Nakamura T, Takio K, Shimasaki S, Ling N, Titani K \& Sugino H 1993 Molecular heterogeneity of follistatin, an activin-binding protein. Journal of Biological Chemistry 268 15579-15587.

Ueno N, Ling N, Ying SY, Esch F, Shimasaki S \& Guillemin R 1987 Isolation and partial characterization of follistatin: a single-chain $M_{\mathrm{r}}$ 35000 monomeric protein that inhibits the release of folliclestimulating hormone. Proceedings of the National Academy of Sciences of the USA $848282-8286$.

Wakatsuki M, Shintani Y, Abe M, Liu Z-H, Shitsukawa K \& Saito S 1996 Immunoradiometric assay for follistatin: serum immunoreactive follistatin levels in normal adults and pregnant women. Journal of Clinical Endocrinology 81 630-634. 
Wang QF, Khoury RH, Smith PC, McConnell DS, Padmanahban V, Midgley AR Jr, Schneyer AL, Crowley WF Jr \& Sluss PM 1996 A two-site monoclonal antibody immunoradiometric assay for human follistatin: secretion by a human ovarian teratocarcinoma-derived cell line (PA-1). Journal of Clinical Endocrinology and Metabolism 81 1434-1441.

de Winter JP, ten Dijke P, de Vries CJM, van Achterberg TAE,

Sugino H, de Waele P, Huylebroeck D, Verschueren K \& van den Eijnden-van Raaij AJM 1996 Follistatins neutralize activin

bioactivity by inhibition of activin binding to its type II receptors. Molecular and Cellular Endocrinology 116 105-114.
Ying SY, Becker A, Swanson G, Tan P, Ling N, Esch F, Ueno N, Shimasaki S \& Guillemin R 1987 Follistatin specifically inhibits pituitary follicle stimulating hormone release in vitro. Biochemical and Biophysical Research Communications 149 133-139.

Yokoyama Y, Nakamura T, Nakamura R, Irahara M, Aono T \& Sugino H 1995 Identification of activins and follistatin proteins in human follicular fluid and placenta. Journal of Clinical Endocrinology and Metabolism 80 915-921.

Received 11 June 1997

Accepted 18 September 1997 